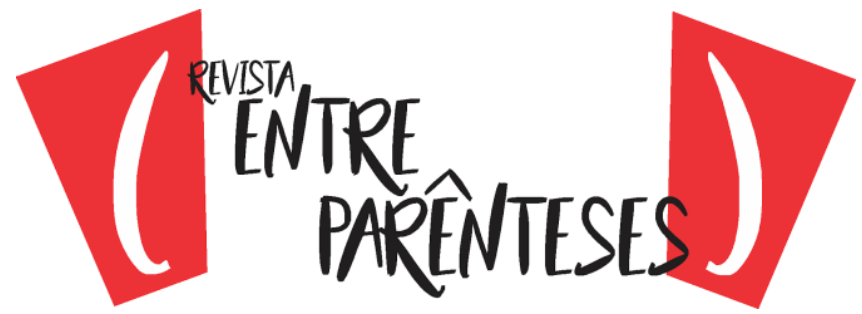

\section{TENSÃO ENTRE ESCRITA E ORALIDADE NO ENSINO- APRENDIZAGEM DO PORTUGUÊS NA ETNIA BALANTA BRASSA (TOMBALI) DA GUINÉ-BISSAU}

\author{
Dábana Namone ${ }^{1}$ \\ Universidade Estadual Paulista Júlio de Mesquita Filho-UNESP \\ (namone2006@yahoo.com.br) \\ Alexandre António Timbane ${ }^{2}$ \\ Universidade da Integração Internacional da Lusofonia Afro-brasileira - UNILAB \\ (alextimbana@gmail.com)
}

\begin{abstract}
Resumo: A política e o planejamento linguísticos da Guiné-Bissau atribuiu o poder ao português desprezando as diversas línguas locais: o crioulo, - a língua falada por pouco mais de $90 \%$ dos guineenses e as línguas étnicas. A pesquisa tem como objetivo analisar a partir de um olhar baseado na perspectiva antropológica, sociológica e sociolinguística sobre a tensão entre a escrita e a oralidade, as consequências da língua portuguesa no processo de ensino-aprendizagem na Guiné-Bissau, especificamente, na etnia Balanta Brassa localizada no sul do país. É uma pesquisa bibliográfica que levanta o estado do problema da implicância do ensino da língua portuguesa na Guiné-Bissau, especialmente na etnia acima mencionada. Da pesquisa observa-se que a Guiné-Bissau possui uma enorme diversidade cultural, na qual coabitam mais de vinte grupos étnicos, com as suas línguas e culturas específicas, fortemente ancoradas na tradição oral. A etnia Balanta tem uma ligação forte com sua tradição oral, através da qual os mais velhos passam ensinamento aos mais novos. Conclui-se que muitos alunos não têm domínio da língua portuguesa devido à interferência das suas línguas maternas; como também não existe uma metodologia adequada para o ensino do português, fatos que criam obstáculos no ensino do país.
\end{abstract}

Palavras-chave: Guiné-Bissau; Português; Oralidade; Escrita; Etnias.

\begin{abstract}
Guinea-Bissau's language policy and planning attributed power to Portuguese by neglecting the various local languages: the Creole, - the language spoken by just over $90 \%$ of Guineans and ethnic languages. The research aims to analyze, from a perspective based on the anthropological, sociological and sociolinguistic perspective on the tension between writing and orality, the consequences of the Portuguese language in the teaching-learning process in Guiné-Bissau, specifically in the Balanta ethnicity Brassa located in the south of the country. It is a bibliographical research that raises the state

\footnotetext{
1 Doutorando da Faculdade de Ciencias e Letras, UNESP

2 Pós-Doutor em Estudos Ortográficos pela Universidade Estadual Paulista Júlio de Mesquita FilhoUNESP (2015), Pós-Doutor em Linguística Forense pela Universidade Federal de Santa CatarinaUFSC(2014), Doutor em Linguística e Língua Portuguesa (2013) pela UNESP, Mestre em Linguística e Literatura moçambicana (2009) pela Universidade Eduardo Mondlane - Moçambique (UEM). É Licenciado e Bacharel em Ensino de Francês como Língua Estrangeira (2005) pela Universidade Pedagógica-Moçambique (UP). Foi professor na Universidade/Academia de Ciências Policiais de Moçambique (ACIPOL) onde lecionou a disciplina de "Introdução à Linguística Forense (Linguagem e Lei)" na Pós-graduação e foi professor de "Língua Francesa" na graduação. Lecionou as disciplinas de "Perturbações de Escrita e de Leitura" e "Metodologia de Investigação Científica" no Instituto Superior de Ciências de Saúde de Moçambique (ISCISA), foi docente de "Estudos do Léxico", "Técnicas de Expressão e de Comunicação" e "Metodologia de Investigação Científica" no Instituto Superior de Gestão e Empreendedorismo Gwaza Muthini-Marracuene (ISGEGM).
}

Revista (Entre Parênteses)

Número 7, Volume 1, 2018 - ISSN 2238-4502 


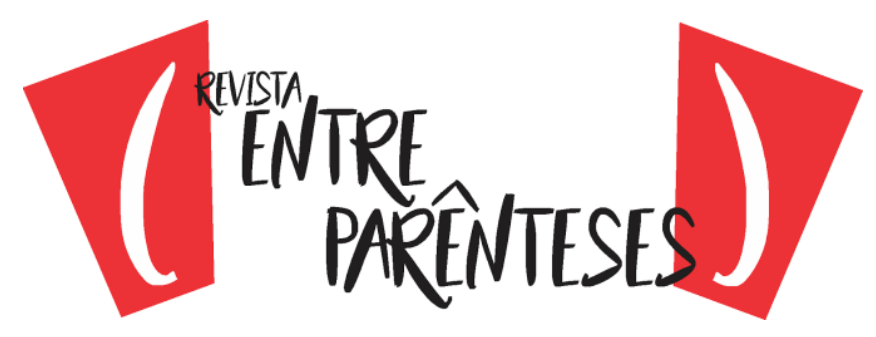

of the problem of the implication of the teaching of the Portuguese language in Guinea-Bissau, especially in the aforementioned ethnicity. The research shows that Guinea-Bissau has an enormous cultural diversity, in which more than twenty ethnic groups coexist, with their specific languages and cultures, strongly anchored in oral tradition. The Balanta ethnic group has a strong connection with their oral tradition, through which the elders teach the younger ones. It is concluded that many students do not have a command of the Portuguese language due to the interference of their mother tongues; as well as, there is no adequate methodology for the teaching of Portuguese, facts that create obstacles in the teaching of the country.

Keywords: Guinea Bissau; Portuguese; Orality; Writing; Ethnic groups.

Resumen: Planificación política y lingüística de Guinea Bissau concedió poder de los portugueses despreciando las diferentes lenguas locales: Criollo, - la lengua hablada por algo más del $90 \%$ de los guineanos y lenguas étnicas. La investigación se propone analizar desde una mirada conjunta en la perspectiva antropológica, sociológica y sociolingüística en la tensión entre la escritura y la oralidad, las consecuencias de la lengua portuguesa en el proceso de enseñanza-aprendizaje en Guinea Bissau, en concreto el origen étnico Balanta Brassa ubicada en el sur del país. Se trata de una investigación bibliográfica que plantea la cuestión del estado del motivo favorito de la enseñanza del idioma portugués en Guinea Bissau, en particular en la carrera antes mencionada. De la investigación se observa que Guinea-Bissau posee una enorme diversidad cultural, en la que cohabitan más de veinte grupos étnicos, con sus lenguas y culturas específicas, fuertemente ancladas en la tradición oral. La etnia Balanta tiene un vínculo fuerte con su tradición oral, a través de la cual los más viejos pasan la enseñanza a los más jóvenes. Se llegó a la conclusión de que muchos estudiantes no tienen conocimientos de portugués debido a la interferencia de sus lenguas maternas; pero también existe una metodología adecuada para la enseñanza del portugués, hechos que crean obstáculos en la educación del país.

Palabras-clave: Guinea-Bissau; portugués; oralidad; escrito; Etnias.

\section{Considerações iniciais}

A Guiné-Bissau é um país africano com cerca de $36.125 \mathrm{~km}^{2}$, localizado na costa ocidental fazendo fronteira ao norte com a República do Senegal, a leste e ao sul com a República da Guiné Conacri e ao oeste é banhado pelo Oceano Atlântico. O país foi uma das cinco colônias portuguesas na África, tendo sido dominado por Portugal desde primeira metade do séc. XVI até ao séc. XX e alcançado a independência unilateral, reconhecida por Portugal em 1974.

O povo da Guiné-Bissau é uma nação rica em diversidade cultural, sendo constituído por diversos grupos étnicos que chegam a vinte, dentre os quais se cita: balanta $(30 \%)$, fulas $(20 \%)$, manjacos $(14 \%)$, mandingas $(13 \%)$, papeis $(7 \%)$, mancanhas, beafadas, bijagos, felupes, nalus, tandas, sussos, mansoancas e 


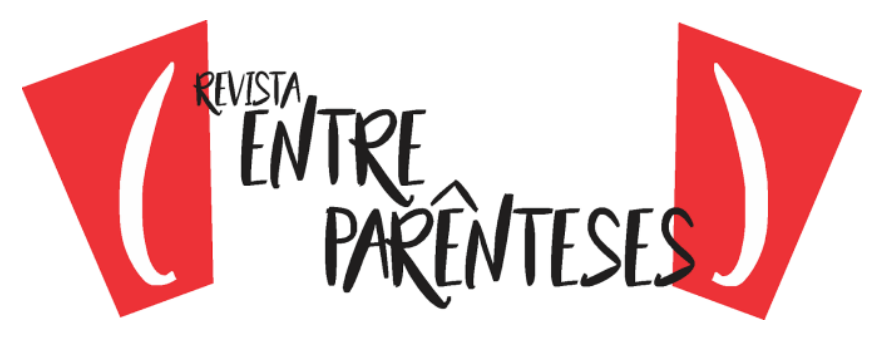

saracules com percentagem igual ou inferior a 1\% (NAMONE e TIMBANE, 2017). Cada grupo possui línguas próprias, embora exista uma família linguística comumlínguas do grupo bantu. A transmissão de conhecimento nessas línguas é baseada na tradição oral, tal como Couto (1994) e Namone (2014) apontam. Desta forma, "cada cultura representa um universo de pensamento e ação absolutamente singular" (BALSALOBRE, 2015, p.105). É importante apontar que a educação escolar guineense deveria reconhecer a educação tradicional dada através da tradição oral para que a educação moderna não se distancie da tradicional. Os provérbios, por exemplo, são formas de educação recorrentes nos povos bantu. Sendo assim, os provérbios poderiam ser adaptados na educação moderna aparecendo nos manuais escolares como forma de valorizar a riqueza cultural existentes no país.

O Estado valoriza o português pelo fato de ser a língua oficial e única língua de ensino (GUINÉ-BISSAU, 1996). Enquanto isso, as línguas locais são desprezadas pela política linguística. O português é falado por 11\% como língua materna (CÁ, 2015; NAMONE \& TIMBANE, 2017). Por isso mesmo, esta língua cria dificuldades no processo de ensino- aprendizagem no país, pois muitos alunos não a falam no seu cotidiano. Destaca-se o caso da etnia balanta brassa, cujos alunos reclamam bastante da metodologia do ensino e dificuldades de aprender português situação que gera reprovações e abandono escolar. Os pais preferem ocupar filhos com trabalho infantil que trará sustento para a família do que matriculá-los nas escolas para repetir de ano várias vezes devido ao fraco domínio da leitura e escrito do português.

A pesquisa tem como objetivos analisar e discutir a partir da perspectiva antropológica, sociológica e sociolinguística a tensão entre a escrita e a oralidade e suas consequências no processo de ensino-aprendizagem do português na etnia balanta brassa localizada na região de Tombali no sul da Guiné-Bissau. É uma pesquisa bibliográfica que levanta o estado do problema da implicância do ensino do português na Guiné-Bissau, especialmente na etnia balanta brassa.

Para a pesquisa, debateram-se conceitos de escrita e oralidade no ensinoaprendizagem do português sob perspectiva antropológica, da sociolinguística e da 


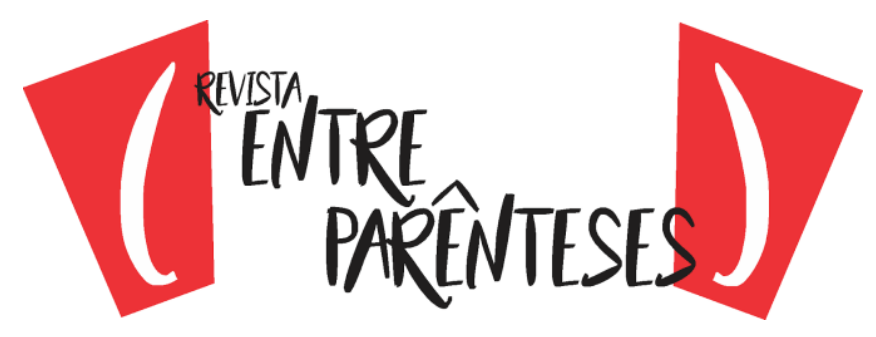

sociologia da educação na perspectiva de Bourdieu sobre o papel político da língua na relação social. Trouxemos também a experiência da nossa vivência na região de Tombali no sul do país, onde reside a maioria dos cidadãos da etnia balanta brassa. Também, ouviram-se relatos sobre as decisões tomadas pelos pais de não matricular seus filhos na escola em decorrência das recorrentes reprovações que estes apresentam o que teve como consequência a não compreensão do português oralmente e por escrita. Nesta pesquisa, o crioulo da Guiné-Bissau será designado de guineense, pelo fato de não existir ainda um nome oficial para designar aquele crioulo.

O ensino não pode ser pesquisado apenas numa só perspectiva ou numa só área de estudos. A multidisciplinaridade é importante para interpretar diversos fenômenos sociais. Cabe afirmar que para estudar e ou compreender a educação numa sociedade multiétnica/pluriétnica cuja tradição oral é a principal forma de transmissão de conhecimento, a antropologia da educação será a principal referencial teórico metodológico. Senão, vejamos:

\section{A relevância da Antropologia da educação em contexto étnico}

Antropologia da educação é de fundamental importância para analisar e compreender a educação em sociedades multiétnicas como o caso da etnia balanta brassa porque a principal forma de transmissão de conhecimentos entre os membros daquela comunidade é a oralidade. Sendo assim, a ciência moderna não se preocupa em estudar problemas da educação para além dos limites do espaço físico escolar ou universitário. Ou seja, a antropologia da educação ajuda na discussão de formas de transmissão de conhecimento a partir da realidade local, formando o que comumente é chamado de currículo local.

Tendo em conta o seu método científico e a sua técnica de pesquisa voltadas para compreender as relações sociais em suas especificidades, consideramos que a antropologia da educação tem um papel central na pesquisa em educação na Guiné-Bissau. A diversidade cultural é vasta e importante para o povo 


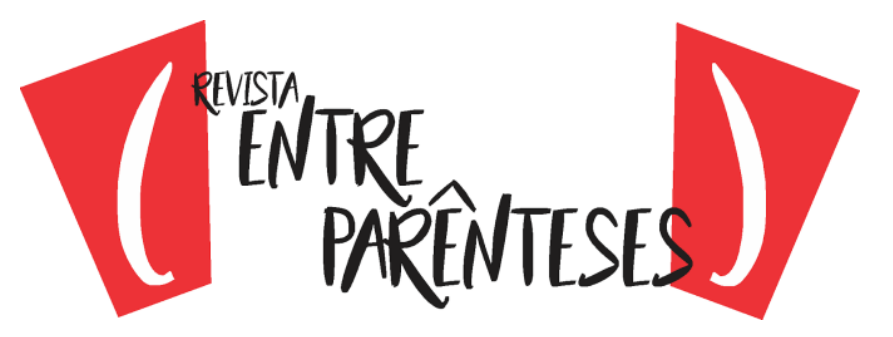

de tal forma que deve ser aproveitada em prol do conhecimento moderno. É nesse sentido que precisamos entender (i) que a escola não é o único lugar em que a educação pode acontecer; (ii) que a educação existe onde a escola formal não foi construída; (iii) que em toda e qualquer sociedade humana, existe aprendizagem inerente à prática social dos seus integrantes; (iv) que os processos educativos ocorrem em meio à vida vivida, como parte das relações humanas que não se restringem ao espaço da escola (ROCHA \& TOSTA, 2009; GUSMÃO, 2011; 2015).

Segundo Tosta (2013), o diálogo entre a antropologia e a educação escolar é de fundamental importância e são necessárias para compreender uma das questões fundamentais na escola: a diversidade cultural e a construção identitária que permeiam os processos de aprendizagem e socialização. A diversidade cultural e identitaria presente nas escolas guineenses não nasceu nas próprias escolas. Representa a realidade cultural do país e é na escola que ela exerce a interação e conflito, pois cada aluno chega com a sua experiência cultural. É nesse contexto que o ensino guineense deve estar preparado para lidar com a diversidade cultural trazida pelos alunos e para dar conta dessa realidade a antropologia da educação torna-se primordial.

Falando sobre "A diversidade cultural em África: o caso do casamento tradicional no grupo étnico tsonga do sul de Moçambique", Timbane e Nhavenge (2018) apontam que a cultura é primordial para a identidade do sujeito e qualquer tentativa de impedi-la é uma violação grave do ego e do pertencimento do sujeito. Desta forma, se escola se recusa a discutir assuntos da cultura e da identidade do local onde o aluno está inserido, está aculturando, desprezando e qualificando a cultura local de 'atrasada' ou 'selvagem.' Os autores mostram que cultura "é o conjunto de práticas, de técnicas, de símbolos e de valores que devem ser transmitidos às novas gerações para garantir a convivência social" (TIMBANE \& NHAVENGE, 2018) e por isso deve ser preservada e estimulada por todos.

Ao tratar da diversidade cultural e da construção da identidade, não se deve esquecer que a língua é um dos elementos centrais nesses processos, pois é 


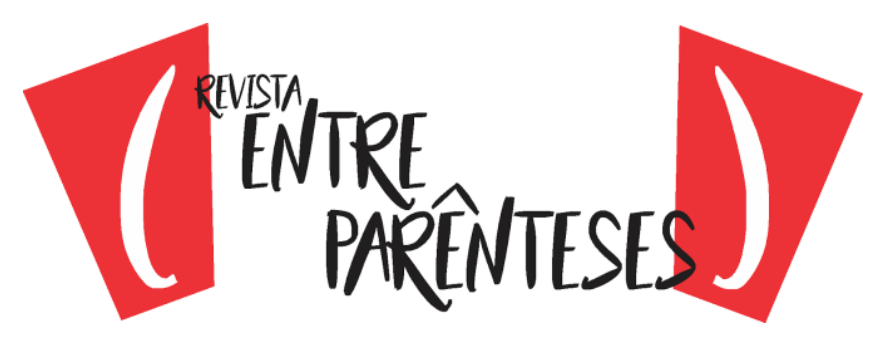

importante compreender que a língua não é apenas um veículo de comunicação de um determinado grupo social, mas também uma ferramenta identitária do grupo. Sendo assim, negar o uso da língua para um balanta, fula, mandinga, papel, bijagó, felupe, ou a qualquer outra etnia é negar a diversidade que constituem essa nação, em proveito da cultura 'estranha' transmitida por meio do português.

Nesse contexto, a língua exerce a função política (BOURDIEU, 1998) de poder, de exclusão e de opressão (TIMBANE \& REZENDE, 2016). Ou seja, seu poder de dominação, qual seja simbólico-cultural, político e econômico, como analisamos ao longo deste trabalho em relação à língua portuguesa. Esse é o desafio que a sociedade atual enfrenta e é uma realidade que a educação guineense enfrenta e que a antropologia da educação pode nos ajudar a desvendar.

A Antropologia da educação nos ajuda a fazer uma abordagem da educação a partir dos métodos e objetos do campo das ciências sociais, especialmente, da antropologia, centrada em processos educativos para além da escola, ou seja, um olhar que supere as visões fechadas da educação, como escolarizada, homogênea e reprodutivista (GUSMÃO, 2011) como a que tem lugar na Guiné-Bissau. Mas também permite destacar a importância da etnografia, na pesquisa educacional, não apenas como instrumento metodológico descritivo utilizado na técnica de coleta de dados, como têm feito muitos pesquisadores de outras áreas disciplinares na Guiné-Bissau sem ter ou sem levar em consideração os conhecimentos teóricos da ciência antropológica.

\section{A tensão entre a oralidade e a escrita na Guiné-Bissau (etnia balanta brassa)}

Como se sabe, os povos bantu são por natureza povos de tradição oral, o que significa que a educação é transmitida de geração em geração através da oralidade, - a chamada contemporaneamente "educação informal". Esta designação é polêmica porque não existe uma "educação informal" quando se refere ao ensino das práticas culturais. Toda prática de ensino tradicional tem uma formalidade, pois é 


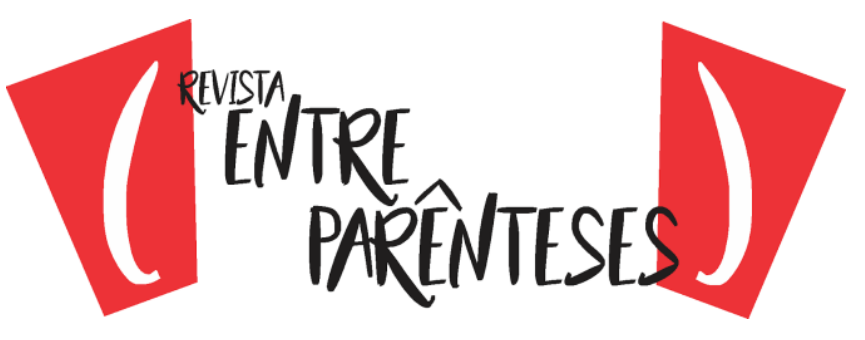

reconhecido pelos régulos, pelos líderes locais, pelas matronas e anciãos da comunidade, logo para africanos se torna absurdo e inconcebível falar que a educação local é informal. Essas declarações só acontecem diante do indivíduo que não conhece a estrutura organizacional de um povo, ou ainda é uma tentativa de desvalorizar a cultura do outro.

A oralidade é inerente ao homem desde os primórdios da humanidade. $O$ homem se aproveitou dos sistemas respiratório e digestivo para produzir o som que Ihe permitiu a comunicação. A escrita é recente e é artificial. Ela não representa a fala, pois é uma modalidade específica de comunicação que é aprendida na escola. A codificação corresponde a escrita e a descodificação a leitura. Surgiu para registrar ideias e pensamentos. A escrita neutraliza a variação e segue a gramática normativa da língua. Na nossa perspectiva é absurdo falar de gramática normativa numa língua. Quem normaliza a língua é a sociedade. Não existe norma sem padrão, mesmo a desprestigiada variante 'caipira' falada no Brasil tem norma-padrão. Mas discutiremos este assunto em fórum adequado. Voltando para a ideia que estava sendo descrita, podemos afirmar que a escrita tem a padronização, mas a fala não tem. Logo, a língua escrita está parada no tempo enquanto que a falada se adapta às condições e situações próprias da cultura e do espaço geográfico em que os indivíduos se encontram. Por essa razão, existe uma tensão entre oralidade e a escrita no ensino dos guineenses. A oralidade e a escrita são duas modalidades diferentes da comunicação cada uma com características próprias.

Marcuschi defende que a "fala e a escrita são diferentes, mas as diferenças não são polares e sim graduais e contínuas. São duas alternativas de atualização da língua nas atividades sociointerativas diárias" (MARCUSCHI, 2010, p.46). Na passagem da fala para a escrita acontece um processo de retextualização e "envolve operações complexas que interferem tanto no código como no sentido e evidenciam uma série de aspectos nem sempre bem-correspondidos da relação oralidade-escrita" (MARCUSCHI, 2010, p.46). 


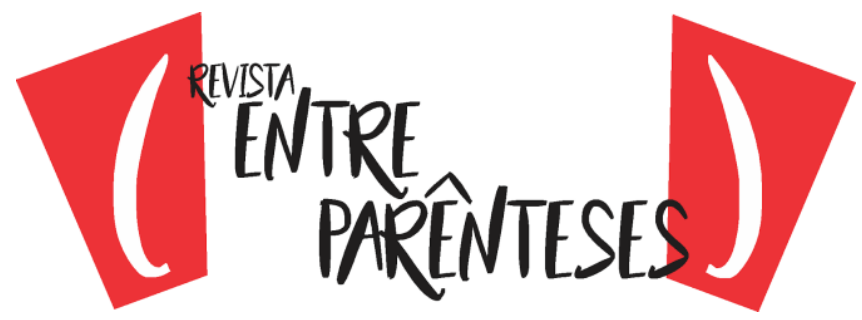

Retomando a formalidade e a informalidade da educação, é importante compreender que essa ideia chegou com o sistema colonial que desejava inferiorizar os ensinos culturais africanos e elevar os sistemas de ensino europeus. A maioria dos países africanos adotou modelo da educação dita 'formal' e a língua do colonizador como a oficial e única do ensino, desprezando os conhecimentos locais transmitidos via oralidade e em línguas locais. Esse foi o maior 'pecado' que 'enterrou' a identidade e acelerou o aculturamento dos africanos (TIMBANE \& NHAVENGE, 2018).

Em todo o mundo, a educação formal é baseada na cultura escrita, considerada como base para o desenvolvimento científico e tecnológico. É através da escrita que se produzem materiais bibliográficos, tais como documentos oficiais, livros, artigos, jornais, programas de computadores e outros materiais que são arquivados em bibliotecas e em outros ambientes podendo servir para futuras pesquisas.

Sendo assim, os povos com cultura oral são tratados como atrasados, analfabetos e subdesenvolvidos, pois os seus conhecimentos são transmitidos oralmente de geração em geração (BÁ, 2010; VANSINA, 2010). As culturas orais são desprezadas pelo fato de os conhecimentos não poderem ser arquivados em documentos escritos correndo risco de se perder ao longo do tempo com a morte dos mais velhos. Se esse argumento fosse verdadeiro, então os balantas não conheceriam a sua história e a cultura ao longo de séculos da sua existência. $O$ problema é que as sociedades modernas a partir do séc. XX pretendem uniformizar e globalizar as formas culturais para que no mundo tenhamos a mesma cultura, a mesma língua, a mesma história, mesma política democrática, a mesma forma de vestir, a mesma gastronomia, tentativas que ao nosso ver redundarão em fracasso se cada etnia ou grupo social se proteger desses ataques da aculturação.

Por outro lado, os conhecimentos culturais são desvalorizados pela 'ciência moderna' porque se acha que neles não existe a cientificidade. Mais uma vez, a ciência moderna apoia que só existe um único caminho para se chegar à veracidade de fatos-usando método científico. Quer dizer, devemos usar o mesmo método e por isso os saberes culturais são chamados de 'conhecimento popular', como se no 


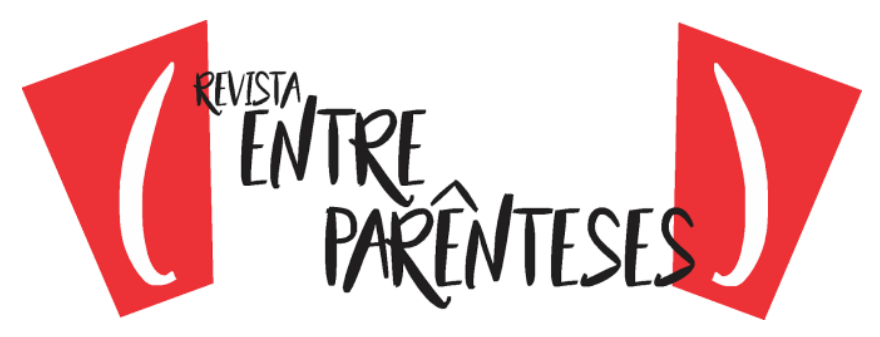

'popular', não houvesse o 'científico' e por outro lado, como se no 'científico', não houvesse o 'popular'. Se o pesquisador trabalha com fatos sociais, está no popular e lida com a sociedade. Quantas vezes os pesquisadores recorrem a questionários, entrevistas e observações como instrumentos de coleta de dados? Será que a oralidade não está presente nessa coleta? É novidade para a cultura africana? É claro que não. A entrevista corresponderia à transmissão do conhecimento por meio da oralidade passando de geração em geração.

É mais um equívoco afirmar que o 'conhecimento popular' não é real, não é sistemático, não é contingente, não tem verificabilidade, não é aproximadamente exato e não é falível, tal como Marconi e Lakatos (2003, p.79) apontam. Quem deseja seguir o método científico utilizará caminhos próprios, mas isso não significa que deve demonizar as outras formas de se chegar à verdade. Não há verdades absolutas. Todas as verdades são válidas segundo o olhar dos seus seguidores. Achamos importante desconstruir essa visão eurocentrista que desvaloriza tudo o que foi produzido fora de África.

Pouca gente se lembra que antes da Europa, em África já havia avanços importantes na medicina (ciência médica e farmacológica avançada, mumificação dos corpos, etc.), na arquitetura (construção de pirâmides, esfinges, templos outras construções), no domínio da natureza (uso plantas para a cura de diversas doenças), na invenção da escrita (no Egito), na astrologia (os povos de Mali já tinham conhecimento da existência do pequenino satélite da estrela Sirius, o Sirius B, invisível a olho nu), na matemática, engenharia, navegação entre outras conquistas ofuscadas pelo fato de serem de origem africana. Pouquíssimas pessoas se lembram de que as primeiras duas universidades do mundo surgiram em África: a Universidade al Quaraouiyine (ano 859) e a Universidade de Al-Azhar (988).

Afirma-se que a tradição oral é um impressionante acervo de conhecimento, pois arquiva na memória dos seus usuários quantidades e importantíssimos conhecimentos ancestrais que são transmitidos de geração a geração. Conhecimentos esses indispensáveis para manutenção das regras de 


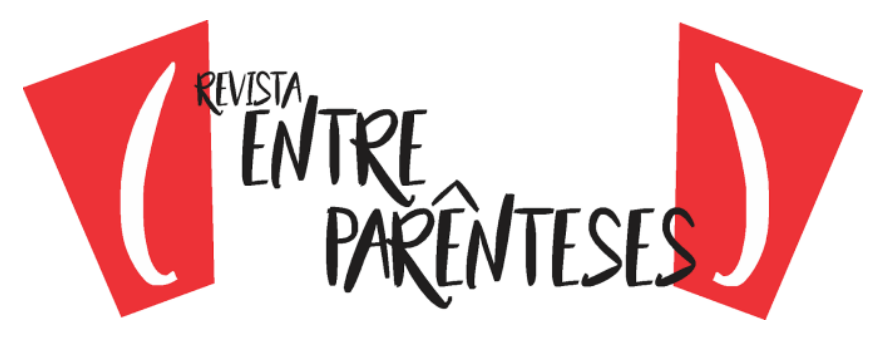

convívio e de relação social nas comunidades que a utiliza. Não é por acaso que a tradição oral continua resistente à educação formal e à cultura moderna, apresentando-se como tradição viva no continente africano (BÁ, 2010). Na África, a educação 'informal' tem como base a tradição oral que nunca parou de existir e ela mantém uma organização sociocultural que sempre está ligada à tradição (TIMBANE, 2015).

Na Guiné-Bissau, a tradição oral é praticada por todos os grupos étnicos desde a ancestralidade até o momento atual, sendo considerada principal forma de transmissão de conhecimentos e de preservação do patrimônio cultural ancestral. Os ritos de iniciação (tais como fanado) praticados principalmente nas zonas rurais do país são uma prova da importância da tradição oral, ou seja, são prova da existência de uma escola tradicional que preserva a cultura que resiste ao tempo e à modernidade. Nessa nação, principalmente, nas zonas rurais o indivíduo que não passou pelos ritos de iniciação é considerado culturalmente imaturo (mesmo tendo diploma universitário ou 100 anos ou mais de idade) porque não possuiu uma formação cultural e por isso não tem legitimidade de participar na tomada da decisão da sua comunidade ou de participar em eventos considerados de adultos. Significa que a o amadurecimento físico deve estar em sintonia com o amadurecimento cultural.

É sabido que muitas das vezes o Estado da Guiné-Bissau recorre aos chefes tradicionais ou às pessoas mais velhas das aldeias (vulgarmente conhecidos como tabanca) para pedir a orientação sobre as medidas que devem ser tomadas para melhorar as políticas públicas tanto nas tabancas como nas zonas urbanas em diferentes áreas: na educação, na saúde, na segurança entre outras. Isso é a demonstração da importância da tradição oral na regulamentação da vida na sociedade guineense. Mas, apesar das ricas orientações dadas pelos mestres das tabancas ao Estado, muitas das vezes elas não são cumpridas. Ou seja, são desprezados. Por exemplo, na educação 'formal' guineense, os conhecimentos da tradição oral, as culturas locais, inclusive as línguas maternas são desprezadas em 


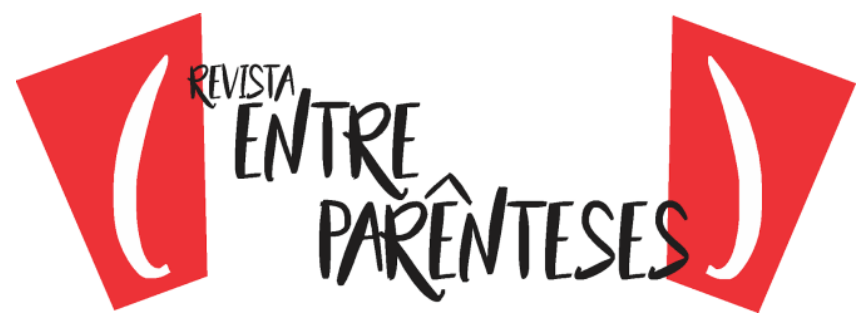

proveito da educação moderna, a cultura do colonizador e a sua língua, neste caso, a língua portuguesa.

É sabido que as ciências modernas se desenvolveram não só pelos conhecimentos da escrita, mas também graças à grande contribuição dos conhecimentos da tradição oral. O caso da medicina tradicional africana. Hoje em dia, por exemplo, a educação formal, aquela que ocorre em instituições criadas pelo governo (as escolas) transmite conhecimentos que muitas vezes já vinham sendo transmitidos pela tradição oral (TIMBANE, 2015). Apesar dessas conquistas tradicionais e explicitadas pela oralidade, o mundo moderno em que vivemos a desvaloriza, considerando conhecimentos populares, mitos, fabulas e tantas outras denominações preconcebidas.

No mundo moderno em que vivemos, ainda existem muitas tensões entre a escrita e a oralidade. $\mathrm{Ba}(2010)$ ressalta que nas nações modernas, onde a escrita tem precedência sobre a oralidade, ela constitui como o principal veículo da herança cultural. Tal como refere Tierno Bokar,

a escrita é uma coisa e o saber é outra. A escrita é uma fotografia do saber, mas não saber em si. O saber é uma luz que existe no homem. A herança de tudo aquilo que nossos ancestrais vieram a conhecer e que se encontra latente em tudo o que nos transmitiram (TIERNO BOKAR apud BA, 2010, p. 167).

Pensar que os povos africanos não têm 'civilização', 'tradição', 'cultura', 'conhecimento' só ocorre em pessoas ignorantes ou com ideologia colonialista e preconceituosa. Pretendemos quebrar esses paradigmas que caracterizamos como 'pensamento ideológico' eurocentrista. Entendemos que qualquer conhecimento é de cunho ideológico. Ou seja, é um olhar etnocêntrico construído na sociedade da cultura escrita, especificamente na Europa Ocidental sobre os povos da cultura oral (povos bantu e koisan). Pelo contrário, está comprovado que povos sem tradição escrita são também detentores de conhecimento científico de alto nível. Muitos curandeiros não sabem ler e nem escrever. Até hoje muitos pesquisadores (especialmente europeus 


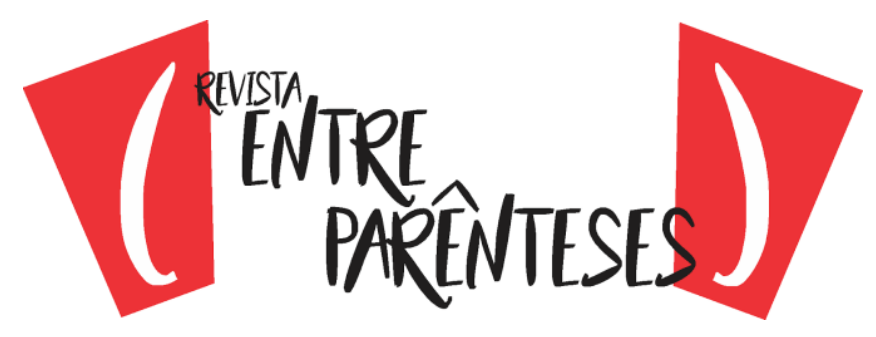

e americanos) da área de saúde vão à África fazer pesquisas e apreender com esses curandeiros sobre as plantas e a sua utilidade medicinal, sempre partindo da oralidade (entrevistas com curandeiros).

Portanto, os conhecimentos da tradição oral são transmitidos pela oralidade, não têm a escrita como preocupação. Muitas línguas africanas são ágrafas, o que não tira a sua legitimidade nem qualidade de línguas. Ser uma língua ágrafa não significa ausência de gramática e de dicionário. Tanto a gramática quanto o dicionário são elementos abstratos que ficam no sistema linguístico, na memória dos falantes e que são reconhecidos, identificados e utilizados pelos falantes de uma determinada língua. Infelizmente, os líderes independentistas africanos não tiveram uma visão ampla da riqueza e da importância das suas línguas como instrumentos de comunicação e de transmissão do saber. O que assistimos é que grande parte dos países africanos colonizados pela Europa adotaram as línguas dos colonizadores como oficiais e únicas de ensino, atitude que desvalorizou as línguas locais que ficaram confinadas nas áreas rurais e isoladas correndo o risco de desaparecer nas próximas décadas. O que falta analisar com muita profundeza é o impacto da 'língua privilegiada' no processo de ensino-aprendizagem nos referidos países, e é o que se pretende abordar na seção a seguir.

\section{Impacto da língua portuguesa no ensino na Guiné-Bissau}

O sistema colonial criou uma ideologia que considerava as línguas locais como dialetos cujos falantes eram desprezados, perseguidos, reprimidos, maltratados como selvagens, primitivos e que seus falares eram chamados de ladim (do inglês land in), línguas dos pretos, línguas de povos selvagens ou ainda línguas dos cães (ZAMPARONI, 2002, grifo nosso). Segundo o Estatuto dos Indígenas Portugueses das Províncias da Guiné, Angola e Moçambique, aprovado por Decretolei de 20 de maio de 1954 (PORTUGAL, 1954), para o africano adquirir o status de civilizado e ter direito à cidadania portuguesa teria que, primeiramente renunciar a sua 


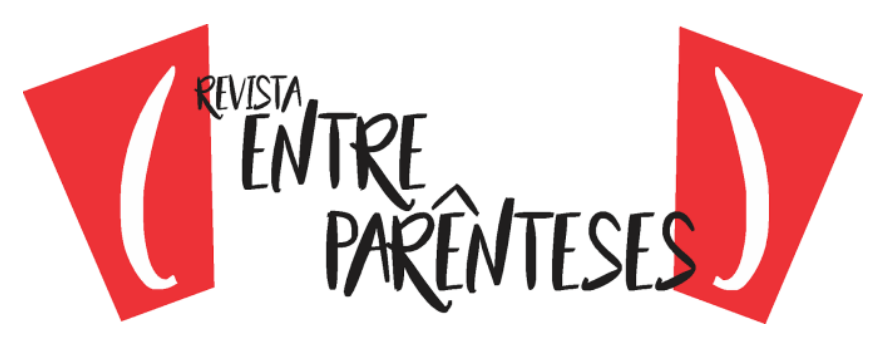

cultura - vista como o que o mantém na condição de selvagem, em proveito da cultura europeia, especialmente, a portuguesa através da passagem pelo processo de 'assimilação' via educação colonial. Ou seja, para adquirir o "estatuto de assimilado", isto é, ser considerado "civilizado" e "cidadão português" seria necessário ao africano preencher um conjunto dos requisitos, entre os quais se cita: Ter 18 anos completos; Saber falar, ler e escrever corretamente a língua portuguesa; Vestir e professar a mesma religião que os portugueses; Ter profissão ou renda que the assegurasse o suficiente para prover as suas necessidades e do número de familiares; Ter bom comportamento, uma vida correta e possuir a instrução e os costumes indispensáveis à aplicação integral do direito público e privado dos cidadãos portugueses; Não estar inscrito como refratário ao serviço militar e não ter desertado (ALMEIDA, 1981; NAMONE, 2014).

Infelizmente, observou-se, que após as independências, os africanos valorizaram esses requisitos deixados pelos colonos criando condições para que as línguas e a cultura africanas desapareçam. Importante assinalar que a educação colonial funcionou na Guiné-Bissau de forma mais visível no final do século XIX após a Conferência do Berlim, principalmente, a partir da década de 1960 até a conquista da independência proclamada pelo Partido Africano da Independência da Guiné e Cabo Verde (PAIGC) em 1973, reconhecida pelo governo português em 1974, embora restrita a poucos africanos, os chamados "assimilados" (os africanos que renunciaram a sua cultura em proveito da cultura colonial no processo da colonização europeia na África, especialmente, nas colônias portuguesas).

No processo da colonização, o português se manteve como a única língua de ensino e de prestígio na sociedade guineense. O domínio da língua portuguesa oferece maiores chances de emprego, além de favorecer o estatuto social privilegiado. Enquanto isso, as línguas locais eram sistematicamente reprimidas e sendo proibidas o seu uso, especialmente nos centros urbanos. A própria língua portuguesa oferece uma série de punições para quem não domina a "norma-padrão" (TIMBANE \& REZENDE, 2016). 


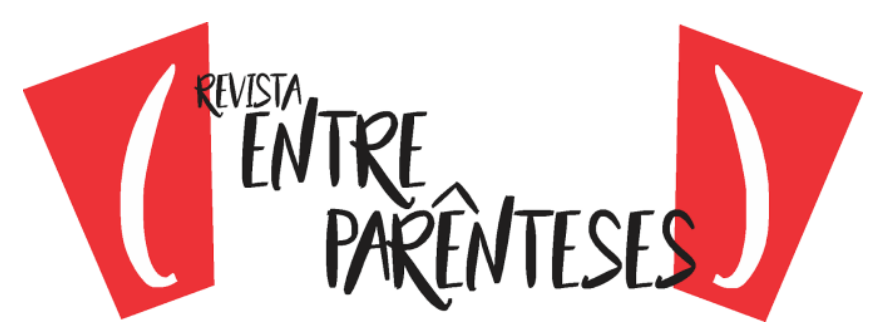

De salientar que no período da luta de independência dessa nação, entre 1963 e 1973, o PAIGC implantou um modelo de educação nas regiões que controlava - a chamada "zonas libertadas". Na sua fase inicial essa educação era dada na língua guineense. O guineense é uma língua africana de base de línguas africanas. É uma língua formada pela contribuição lexical de língua portuguesa e contribuição gramatical das diversas línguas africanas faladas na região da África ocidental. Registramos aqui, a ideia de que o crioulo da Guiné-Bissau não é de base portuguesa. A base de uma língua é o sistema, é a gramática e não o léxico. Nossos estudos (que divulgaremos em breve) demostrarão que o guineense é de base de línguas africanas tendo recebido uma contribuição lexical de português, tal como qualquer língua recebe palavras vindas de outras línguas. O próprio português recebeu na sua língua contribuições do árabe, mas isso não nos autoriza afirmar que o português é de base árabe.

Infelizmente, o próprio líder do PAIGC, Amílcar Cabral não entendeu a importância das línguas africanas chegando a afirmar equivocamente o seguinte:

Para nós tanto faz usar o português, como o russo, como o francês, como o inglês, desde que nos sirva, como tanto faz usar tractores [tratores] dos russos, dos ingleses, dos americanos, etc., desde que tomando a independência, nos sirva para lavrar a terra [...] Muitos camaradas, com sentido oportunista, querem ir para frente com 0 crioulo. Nós vamos fazer isso, mas depois de estudarmos bem. Agora a nossa língua para escrever é o português. Afinal, o português (língua) é uma das melhores coisas que os tugas nos deixaram, porque a língua não é prova de nada mais senão um instrumento para os homens se relacionarem uns com os outros [...] A língua é um instrumento que o homem criou através do trabalho, da luta para comunicar com os outros [...] Nós, Partido, se queremos levar para frente o nosso povo, durante muito tempo ainda para escrevermos para avançarmos na Ciência, a nossa língua tem que ser o português. $E$ isso é uma honra. É a única coisa que podemos agradecer aos tugas (CABRAL, 1990, p. 59).

Foi a partir do discurso de Cabral que o português foi adotado como a única de ensino nas zonas libertadas. Tais zonas libertadas eram regiões do interior/zonas 


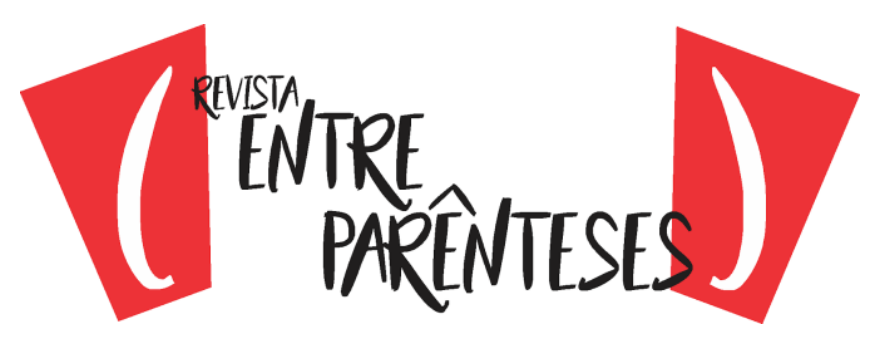

rurais da Guiné-Bissau, compostas por diversidades dos grupos étnicos. O sonho de ensino através do crioulo da Guiné-Bissau se perdeu definitivamente quando se alcança a independência, pois a política linguística oficializou apenas o português como a única língua oficial afastando o crioulo e as restantes línguas étnicas faladas pela maioria da população. Timbane (2015) relata uma experiência interessante na África do Sul, país que oficializou 11 línguas das quais 9 são africanas, graças a visão do grande líder Nelson Mandela.

A Guiné-Bissau é um dos países africanos com altas taxas de analfabetismo especialmente nas zonas suburbanas e rurais. $O$ grande problema é o ensino em língua portuguesa porque grande maioria dos alunos, principalmente das zonas rurais nascem e crescem sem ter contato nenhum com o português. $O$ contato com o português inicia na $1^{\underline{a}}$ série de ensino com 7 anos, atitude que dificulta a aprendizagem. Mas, apesar de todo esse complexo problema sociolinguístico, a política e o planejamento linguísticos adotados pelos governantes guineenses favoreceram a língua do poder deixando de lado as línguas maternas dos guineenses, incluindo o guineense. Segundo Namone \& Timbane (2017) o impacto da escolha do português como a única língua de ensino se observa no dia a dia. Muitos alunos repetem de classe, muitos jovens desistem da escola, muitos pais procuram orientar seus filhos para as atividades produtivas que trarão sustento, pois não conseguem ver o futuro da escola. Sendo assim, o contexto multilíngue dificulta a aprendizagem do português até porque os professores estão despreparados metodologicamente para lidar com este tipo de ensino.

Enquanto os guineenses não reconhecerem o português guineense, os alunos enfrentarão dificuldades. O português correto não é aquele falado em Portugal nem no Brasil. É necessário repensarmos a questão de norma-padrão. A normapadrão sempre cria barreiras e inibe mesmo aqueles que têm o português como língua materna. O português da escola é diferente do português de casa e da comunidade de fala, o que prova a artificialidade da norma-padrão. Seria importante valorizar a variedade guineense do português, incentivando pesquisas que descrevam a 


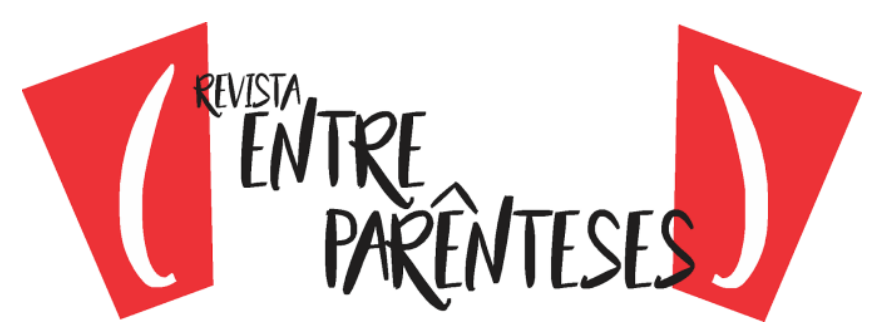

variedade assim como a publicação de dicionários e gramáticas. O maior perigo do ensino atual é a formação de analfabetos funcionais. Entende-se por analfabetos funcionais a insuficiência ou incapacidade de conhecimento que um egresso tem em realizar atividades de cálculo matemático simples, de leitura, de interpretação e escrita de textos simples que deveria saber para aquele nível. O resultado desse tipo de analfabeto é a manutenção do estado das coisas, pois os analfabetos funcionais são incapazes, não farão nenhuma mudança nem diferença para a sociedade e nem complicarão as intenções de políticos desonestos, corruptos e 'sugadores' do povo.

\section{Papel da língua oficial na relação social: caso de educação na Guiné-Bissau (etnia balanta brassa)}

Na região de Tombali, no Sul da Guiné-Bissau distante da capital - Bissau, quase ninguém fala português no seu dia a dia, salvo na cidade de Catió - a sede regional. Apesar dessa situação, os alunos são obrigados a falar português na aula e no recinto escolar. O guineense) é o mais falado nas cidades, sobretudo, quando pessoas de etnias diferentes desejam se comunicar. Nas aldeias da região de Tombali ninguém fala português, os moradores falam diariamente as suas línguas étnicas. Os grupos étnicos mais predominantes nessa região são os balanta brassa - conhecidas também como balanta de Nhácra.

Esses balantas são grandes agricultores de arroz e outros cereais, assim como são criadores de gados principalmente os balanta brassa que imigraram de norte do país para sul em busca das melhores terras para agricultura, pois a região possui solos e condições climáticas favoráveis a práticas da agricultura. Mas, por outro lado, é uma das regiões do país com pouca infraestrutura estatal no sentido geral.

Nos estudos de Bourdieu a respeito do papel político que a língua tem, mostra-se que a língua oficial desempenha uma função de mercado econômico. No mercado linguístico, segundo o autor, "as trocas linguísticas, isto é, as relações de comunicação por excelência são também relações de poder simbólico onde se 


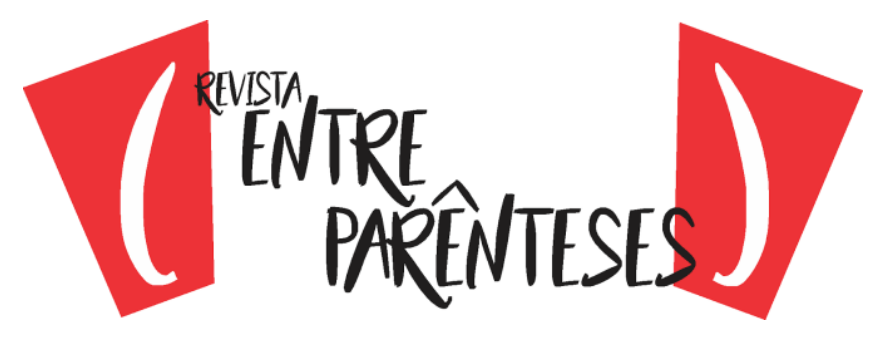

atualizam relações de força entre locutores ou seus respectivos grupos" (BOURDIEU, 1998, p. 23-24). Ou seja, a troca linguística é também, "uma troca econômica que se estabelece em meio a uma determinada relação de força simbólica entre um produtor, provido de um dado capital linguístico, e um consumidor (ou um mercado), capaz de propiciar um certo lucro material ou simbólico" (BOURDIEU, 1998, p. 53). Bourdieu (1998) nos alerta que a língua é fenômeno social que ultrapassa a sua dimensão simbólica interna e envolve a dimensão externa, em diversos aspectos: geográficos, etnológicos, históricos e políticos dos seus falantes. Nesse sentido, segundo Antunes,

a língua deixa de ser apenas um conjunto de signos (que tem um significante e um significado); deixa de ser apenas um conjunto de regras ou um conjunto de frases gramaticais, para se definir como 'um fenômeno social, como uma prática de atuação interativa', dependente da cultura de seus usuários, no sentido mais amplo da palavra. Assim, a língua assume um caráter político, um caráter histórico e sociocultural, que ultrapassa em muito o conjunto de suas determinações internas. Ainda que consistentes e sistemáticas (ANTUNES, 2009, p.21).

Importante reafirmar que é na dimensão da língua que a perspectiva sociológica de análise linguística desenvolvida por Bourdieu se diferencia da perspectiva linguística clássica desenvolvida por Saussure. Se a perspectiva linguística clássica de Saussure dá importância a dimensão interna da língua, a perspectiva sociológica de Bourdieu direciona seu foco para a dimensão externa. Pois, para Bourdieu (1998) é nessa dimensão que a língua exerce a sua função política de dominação. Sendo assim, de acordo com o autor, é no mercado linguístico que a língua oficial desempenha um papel de destaque na relação de consumo entre o produtor e o receptor, pois, para o autor,

o que circula do mercado lingüístico não é a língua , mas, discurso estilisticamente caracterizados, ao mesmo tempo de lado da produção na medida em que cada locutor transforma a língua comum num idioleto e do lado da recepção na medida em que cada receptor contribui para produzir a mensagem que ele recebe e aprecia 


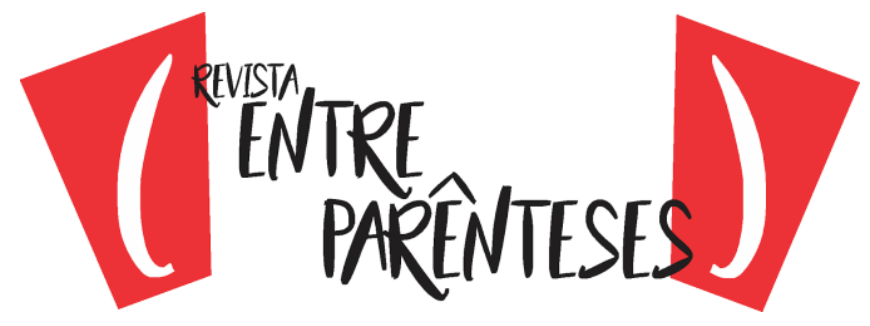

importando para ela tudo o que constitui sua experiência singular e coletiva (BOURDIEU, 1998, p. 25).

Bourdieu (1998, p. 53) defende que "os discursos não são apenas a não ser excepcionalmente signos destinados a serem compreendidos, decifrados; como são também signos de riqueza a serem avaliados, apreciados, e signos de autoridade a serem acreditados e obedecidos". A língua oficial está enredada com o Estado, tanto em sua gênese como em seus usos sociais, sendo inculcada por este e legitimada pelos seus aparelhos ideológicos: a escola e várias outras instituições públicas. $\mathrm{Na}$ concepção do Bourdieu (1998), é na formação do Estado-nação que se criam as condições que legitimam o mercado linguístico. Mercado esse que confere poder à língua oficial, vista enquanto elemento regulamentador de todas as práticas linguísticas.

É no processo de constituição do Estado que se criam as condições da constituição de um mercado linguístico unificado e dominado pela língua oficial: obrigatória em ocasiões e espaços oficiais (escolas, entidades públicas, instituições políticas etc), esta língua de Estado torna-se a norma teórica pela qual todas as práticas linguísticas são objetivamente medidas (BOURDIEU, 1998, p. 32).

Cabe lembrar que campo linguístico enquanto sistema de relações de força propriamente linguísticas é fundado na distribuição desigual do capital linguístico (BOURDIEU, 1998), onde a língua legitima - a língua oficial e tende a se sobrepor às outras em torno, através de diversos mecanismos entre os quais: a autoridade a ela delegada e prestígio social que confere aos seus usuários. A língua portuguesa não se distribui de forma igualitária na Guiné-Bissau, ela restringe-se principalmente na capital Bissau e em algumas cidades do país, como referimos ao longo deste trabalho, enquanto a população do interior - a maioria no país desconhece tal língua, só fala as suas línguas étnicas e alguns nem sabem falar ou não falam fluentemente o guineense. É neste caso que o poder de atuação da língua do colonizador - língua portuguesa acaba sendo limitado, tendo em conta o enraizamento e a interferência 


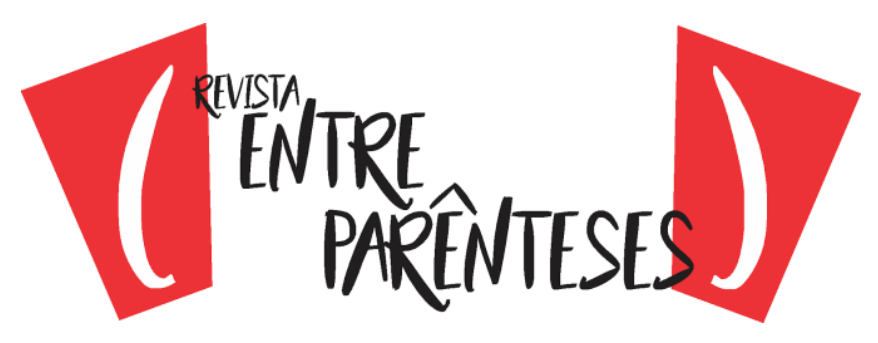

das línguas locais no dia a dia da população. O que dificulta o sucesso dessa língua "oficial" no ensino.

Contudo, de acordo com nossa leitura, a autoridade a ela destina os prestígios sociais: emprego, oportunidade de passar num processo seletivo para bolsa de estudos, etc, que ela confere aos seus usuários, ou seja, a quem a fala fluentemente, - principalmente, as pessoas mais influentes no país em termos de capital: cultura, social ou econômico (BOURDIEU, 1987; 1998, grifo nosso), a autoridade faz com que esse idioma seja legitimado como a língua oficial e seja mantido como a única de ensino no país.

É exatamente aí que reside o problema social da educação guineense. Isto é, o problema que visa à reprodução do ciclo de desigualdade social a partir da educação (BOURDIEU \& PASSERON, 1970), pois, tanto as línguas étnicas como o guineense são proibidas no recinto escolar. $O$ aluno que desobedece pode ser punido com sanções disciplinares, tais como falta de disciplina, ou até expulsão da sala de aula. A única língua aceite e legitimada pela escola é a língua portuguesa. Essa atitude demonstra o alto grau de intolerância linguística praticada pelo Estado guineense, contra a sociedade, especialmente os alunos. Segundo Cá, (2015),

as crianças guineenses entram em contato com o mundo da cultura escrita escolar, sendo privadas dos conhecimentos linguísticos prévios já adquiridos, tanto na aquisição de uma das 25 línguas pertencentes aos diferentes grupos étnicos que constituem nossa população como também conhecimentos culturais e práticas de letramento relacionadas ao crioulo, língua nacional (CÁ, 2015, p.18).

Impacto do desprezo das línguas locais na educação na Guiné-Bissau já era preocupação de alguns especialistas em educação, desde anos após a conquista da independência. Por exemplo, Freire (1978), nas suas visitas ao país, já apontava a importância de a alfabetização acontecer em guineense, que é língua mais falada por grande parte dos guineenses e conseguintemente nas línguas étnicas dos alunos. Freire (1978) percebeu a urgência da utilização das línguas locais no processo de ensino-aprendizagem, tendo em conta a experiência de ensino no Brasil. Ele já previa 


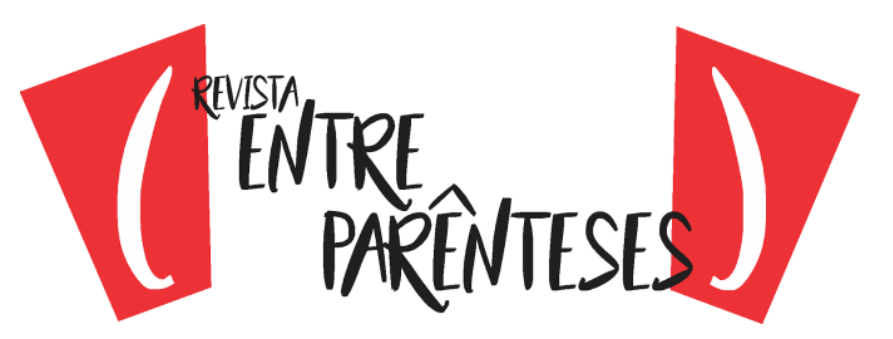

o insucesso escolar, o abandono escolar e a qualidade da educação partindo da análise da situação sociocultural e econômico do país.

Além de tudo isso, a língua de um povo é também, o fator da sua identidade. Não é por acaso que a UNESCO insiste em defender que a educação deve ser dada na língua materna do aluno. A Declaração Universal dos Direitos Linguísticos (UNESCO, 1996) determina que "todas as comunidades linguísticas têm o direito de organizar e gerir os seus próprios recursos, com vista a assegurarem o uso da sua língua em todas as funções sociais". Isso porque segundo a UNESCO, a língua, seja qual for é um direito fundamental de seu povo, portanto fator de identidade. Então, não existe dialeto, pois cada língua tem o seu lugar de origem, seus usuários a tem como um direito fundamental. Nesse sentido, chamar uma língua de dialeto significa, segundo alguns pesquisadores, uma manifestação de preconceito linguístico e hierarquia entre línguas atitude que não devia acontecer (HAUGEN, 2001; TIMBANE, 2013).

Nesse sentido, podemos afirmar, com bastante propriedade, que o que acontece com a política linguística levada a cabo na Guiné-Bissau é uma manifestação de preconceito linguístico, uma vez que línguas locais faladas pela maioria dos guineenses são proibidas na escola e a língua portuguesa que, na verdade, preenche lugar de língua segunda ou língua terceira de alguns guineenses é valorizada, imposta e protegida pela lei magna da nação como a única oficial e do ensino. No primeiro parágrafo do artigo $17^{\circ}$ da Constituição da República da GuinéBissau consta que "o Estado preserva e defende o patrimônio cultural do povo, cuja valorização deve servir o progresso e a salvaguarda da dignidade humana" (GUINÉBISSAU, 1996). Se a língua é um patrimônio cultural de um povo, portanto, as línguas maternas dos diversos grupos étnicos da Guiné-Bissau são seus patrimônios culturais que deveriam ser valorizadas, defendidas e preservadas, o que não tem acontecido no país.

É incalculável o grau de desastre que isso provoca na educação do país, pois os alunos guineenses enfrentam problemas sérios na escola com relação à 


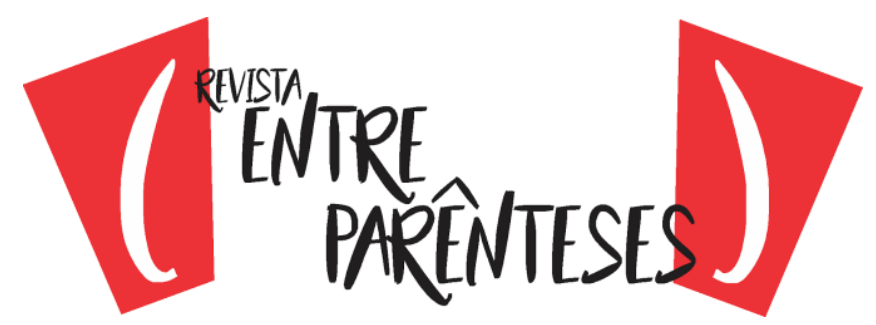

aprendizagem do português, pelo fato de que em casa falam as suas línguas maternas e quando chegam à escola são obrigados a falar português. Todas as disciplinas curriculares (matemática, história, geografia, ciências sociais, ciências naturais, educação visual, física, química, filosofia, psicologia) são ensinadas em português, junto com a própria língua portuguesa enquanto disciplina. Esse cenário, seguindo os estudiosos em educação e linguística vem provocando consequências gravíssimas aos alunos guineenses, tais como: as reprovações e abandono escolar em larga escala, pois a língua que são obrigados a apreender na escola é diferente das línguas que falam em casa e grande parte desses alunos começam a ter contato com a língua portuguesa na escola (COUTO \& EMBALÓ, 2010; SCANTAMBURLO, 2013, CÁ, 2015; NAMONE \& TIMBANE, 2017).

\section{A falta de qualificação adequada dos professores e ausência de condições materiais}

Ainda no que diz respeito ao insucesso da língua portuguesa na educação guineense e da sua consequência direta nos alunos, segundos os especialistas, a falta de qualificação adequada dos professores também tem a sua contribuição nesse contexto. Cruz (2013) afirma que

O português tem tido muitas dificuldades para se afirmar como a língua de comunicação no contexto escolar, isto para não falarmos no quotidiano da vida social dos guineenses. Esta situação advém da fragilidade do sistema educativo e do fracasso generalizado no processo de ensino e aprendizagem do português, sobretudo devido à falta de preparação linguística adequada dos professores, independentemente da sua disciplina de especialização (CRUZ, 2013, p. 34).

Se os professores que recebem formação em português têm dificuldade na expressão tanto escrita como oral, quais resultados esperamos? Segundo Candé (2008) e Cruz (2013), os professores têm dificuldades no uso do português, fato que 


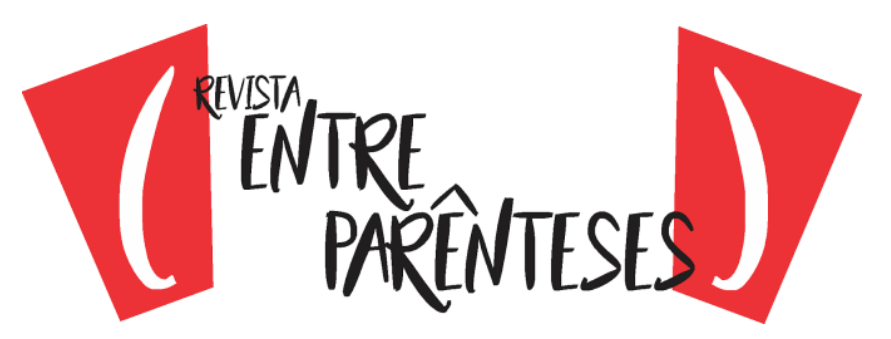

não contribui para desenvolvimento da proficiência do aluno, pelo contrário aumenta seu grau de dificuldade de aprendizagem da referida língua. De acordo com Candé (2008),

\begin{abstract}
apesar das preocupações e esforços para o aumento da qualidade de ensino em geral e das estratégias para o desenvolvimento do ensino da língua portuguesa, as atividades de formação e reciclagem de professores em serviço e dos formadores nesta área não são suficientes para dar uma resposta satisfatória às necessidades do Sistema Educativo guineense no que toca ao desenvolvimento da língua portuguesa e ao sucesso escolar (CANDÉ, 2008).
\end{abstract}

Como se pode observar, o privilégio atribuído à língua portuguesa é resultado da política e do planejamento político iniciado pelo sistema colonial e apoiado pelo primeiro Governo independentista de 1974 e que permaneceu assim até hoje. Mas as consequências do ensino do português são bem visíveis, a partir do rendimento escolar de alunos nos ensinos fundamental (primário), médio (secundário) e superior. O português não sendo uma língua que os alunos guineenses usam no dia a dia, o que se verifica é que decoram "frases mecanicamente, sem nenhum senso crítico" (COUTO \& EMBALÓ, 2010, p.41). Isso acontece porque o ensino de "língua portuguesa é desenvolvido por processos didáticos que se assentam na repetição e na memorização" (CRUZ, 2013, p. 35), e quando chega o momento da avaliação, os alunos não conseguem desenvolver seu próprio raciocínio. A metodologia da memorização inibe a criatividade do aluno e faz com que a aluno fique preso em frases pré-elaboradas e ditas pelo professor.

O aluno pode até decorar as matérias mecanicamente, com intuito de vir a reproduzi-las por escrito na prova para com isso conseguir uma nota positiva, mas pode acontecer que as matérias que ele decorou não são as mesmas que caem na prova. Aí, o aluno cai em desespero, porque sabe que não vai conseguir ter êxito na prova, ou seja, vai tirar nota negativa. $O$ aluno pode até entender o assunto, sem precisar fazer 'cábula' ou 'cola', mas não consegue expressar oralmente ou por escrito na língua portuguesa. Tudo isso traz graves consequências para o próprio aluno em 


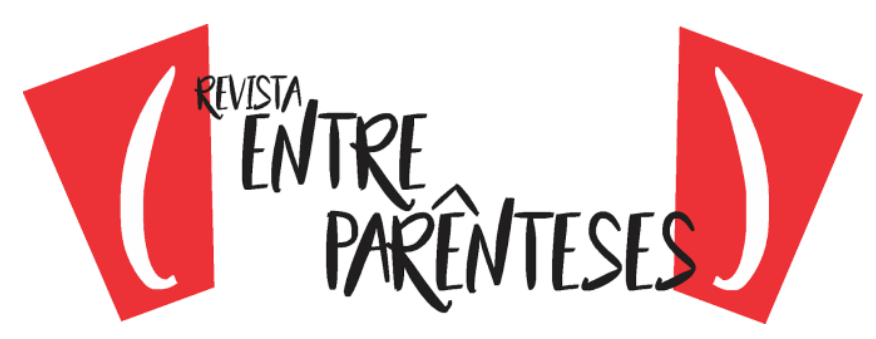

particular e para o sistema de ensino em geral. Como por exemplo, maior índice de reprovações e abandono escolar, fato que também não contribui na melhoria de qualidade da educação.

Se a dificuldade de alunos em aprenderem o português acontece na cidade, onde muitos têm contato razoável com a língua oficial, imagine no interior do país, onde os alunos falam permanentemente as línguas éticas de africanas, onde todos os valores educativos tradicionais ensinados pela tradição oral? É essa realidade que pretendemos apresentar e discutir procurando possíveis soluções.

Se o Governo não aposta na formação de professores de qualidade e não oferece um ensino de qualidade (em língua portuguesa e em línguas locais) quem fica em vantagem são os políticos. Se o Governo não oferece ensino gratuito e obrigatório no ensino primário, secundário e superior quem fica em vantagem são os políticos. Se o ensino público for de baixa qualidade e se os alunos reprovam e desistem quem fica a ganhar são os políticos. Se os alunos terminam níveis de ensino sem qualidade exigida e se tornam analfabetos funcionais quem sai a ganhar são os políticos. Por quê? Porque quanto mais tiver eleitores analfabetos (ou analfabetos funcionais) sem conhecimento dos seus direitos e deveres, mais facilmente serão manipulados e induzidos ao voto errado. Estava muito certo Nelson Mandela, líder sul-africano quando afirmou "A educação é a arma mais poderosa que você pode usar para mudar o mundo". E nós acrescentamos que se a arma mais poderosa não tiver nenhuma munição, essa arma não serve para nada também. Uma arma sem nenhuma munição não é nada, não serve absolutamente para nada. Em outras palavras, um ensino fraco que não prepara efetivamente o cidadão para enfrentar os desafios do mundo em todos os aspectos, então esse ensino não ajuda em nada para sociedade nova que desejamos. Ki-Zerbo (2006, p.150-151, grifo do autor) diz que

a educação deve ser considerada como 0 coração do desenvolvimento. Isso justifica-se muito mais hoje, porquanto 0 principal investimento é o da inteligência, da matéria cinzenta. Mais do que nunca, a educação e o desenvolvimento devem ser postos em equação, na condição de tratar-se de uma educação adaptada. É aqui

Revista (Entre Parênteses)

Número 7, Volume 1, 2018 - ISSN 2238-4502 


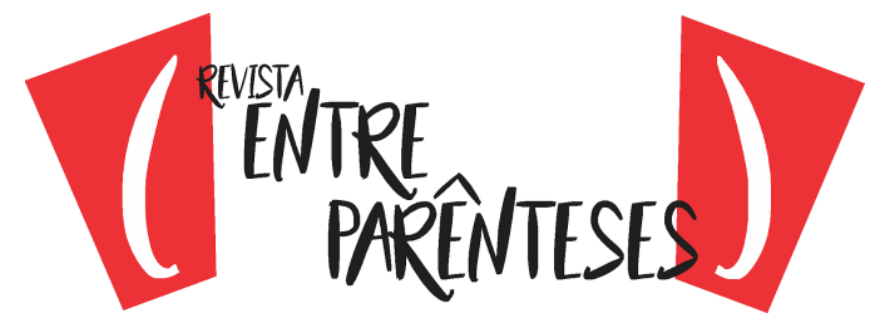

que é necessário sai do mimetismo, da cópia pura e simples dos modelos vindos de fora. Tal como existe hoje, a educação é um processo antidesenvolvimento. A maioria das crianças africanas recebe hoje uma educação que destrói o seu futuro em todos os planos.

Ki-Zerbo coloca a educação como o coração do desenvolvimento. Países que acreditam no desenvolvimento apostam num ensino de qualidade para que os cidadãos possam empreender no país e contribuir para o desenvolvimento. Quem são os jovens que iniciaram as lutas armadas de libertação contra o colonialismo em África? Foram graduados, mestrados e doutores formados na sua maioria na Europa (Portugal, Inglaterra, França, Rússia, etc) e nos Estados Unidos. Foram acadêmicos que viram a necessidade de "pegar em armas" e lutar contra o colonialismo. Por isso que, até hoje, poucos Estados africanos oferecem maior bolo de arrecadação de impostos para o setor da educação e pesquisa científica, pois políticos (malintencionados) estão cientes do fato de que educar é formar 'cabeças pensantes' que poderão questionar certas atitudes no futuro. O problema da Guiné-Bissau é o problema da África toda. Estamos numa nova era que, desde já, designamos de autocolonialismo camuflado. A designação autocolonialismo surge para dar conta da situação quando alguém está "livre" e procura colonizar-se a si mesmo, prejudicando a si e aos seus próximos, na mesma nação, no mesmo povo. Um autocolonialista é um autêntico egoísta, pois pensa em si mesmo e na sua família e esquece as pessoas que estão em sua volta. Líderes autocolonialistas brigaram junto com o povo para o alcance da independência colonial, mas, "vira e mexe", os mesmos tentam sabotar a sua própria pátria roubando as riquezas, entregando as riquezas aos estrangeiros em seu próprio benefício e não investindo na educação.

São muitos exemplos que ilustram o autocolonialismo em África. Países nessa situação têm características em comuns: (i) seus cidadãos fogem para países vizinhos ou vão para Europa, América ou Ásia; (ii) índices de fome elevados e elevadas taxas de pobreza absoluta; (iii) guerras que não acabam; (iv) altas percentagens de doenças como Sida (aids), tuberculose e outras crônicas; (v) baixa 


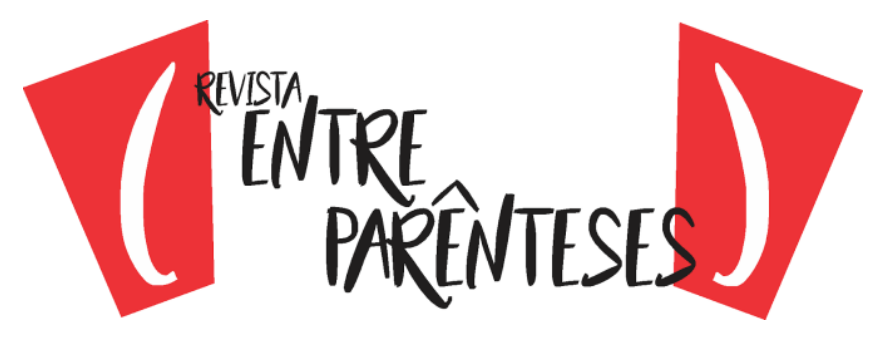

qualidade de ensino e altas taxas de analfabetismo; (vi) maioria da população pobre (vivendo com menos de 1 dólar/dia) e uma minoria riquíssima; (vii) riquezas naturais entregues aos estrangeiros e (viii) líderes com características de ditadores e/ou com 40 ou 50 anos após a independência na mesma situação socioeconômica (muita pobreza, população descontente e corrupção escancarada).

É nesse sentido que considero que muitos alunos guineenses, especificamente os pertencentes à etnia Balanta Brassa do Sul tiram notas negativas e reprovam ou abandonam a escola porque têm dificuldades de ler, escrever e falar a língua portuguesa, devido ao fato de não ter contato permanente com essa língua, como também, por ela não ser adequadamente ensinada segundo uma metodologia própria de língua segunda ou terceira que ela é nessa realidade social. Consideramos que esses fatos desmotivam muitos pais que resolvem tirar seus filhos/filhas da escola por achar que eles/elas não são capazes de estudar e passar nas provas através da língua portuguesa.

$\mathrm{Na}$ época em que eu estudava no ensino primário e muito tempo depois pelo que venho acompanhando, muitos jovens, adolescentes e crianças balantas abandonam a escola justificando a dificuldade de compreensão escrita e oral da língua portuguesa, que é a única de ensino na Guiné-Bissau. Outros não são matriculados pelos pais por acharem que eles não têm cabeça para estudos, em consequência de mau desempenho escolar que apresentam, sendo que, na verdade, esses alunos não entendem e têm dificuldade de expressão oral e escrita na língua portuguesa. Por outro lado, o estado nada faz para reverter a situação pelas razões acima apresentadas.

A realidade escolar guineense, sobretudo a política linguística é tão distante da realidade sociocultural e linguística local, neste caso, a realidade dos balantas brassa, a ponto de muitos pais não verem a importância da escola na vida dos seus filhos. Ainda quando esses estudam o ano inteiro e no final chegam a casa dando notícia de que reprovaram. Isso abala o psicológico tanto dos próprios alunos que ficam desmotivados chegando a abandonar os estudos, como dos pais que resolvem 


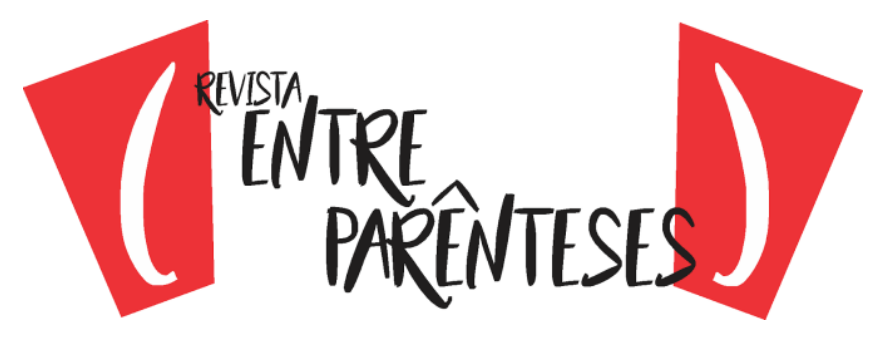

não mais matricular seus filhos para escola, evitando os custos dos materiais escolares e do transporte casa-escola.

Estudar nessa realidade é muito difícil, muitas das vezes, os alunos deslocam muitos quilômetros a pé porque a tabanka onde vivem não tem aquele nível de ensino. Isso gera não só esforço físico e mental para os alunos, como também gera custos para os seus pais que arcam com as despesas dos estudos dos filhos, tais como alimentação e moradia. Não se deve perder de vista o fato de que, para falar ou escrever uma língua, exige-se ter no mínimo conhecimento de sua estrutura: gramatical, fonético, lexical, sintática, pragmática entre outras. E um aluno balanta brassa que nasceu e cresceu falando a sua língua materna sentirá dificuldades se for ensinado por professor despreparado com falta de recursos materiais e infraestruturais. Aprender uma língua não acontece de noite para o dia e nem basta conhecer a gramática. É necessário conhecer a pragmática.

\section{Considerações finais}

A Guiné-Bissau enfrenta grande dificuldade na educação escolar. Uma das principais causas é a língua portuguesa adotado como a única de ensino. Enquanto isso, as línguas locais faladas pela maioria dos guineenses são desprezadas, abandonadas e proibidas na escola. No país a cultura oral e os conhecimentos ensinados através da tradição oral são também desprezados, em proveito da educação "formal" calcada na cultura do colonizador e na língua portuguesa. A educação escolar dada nas escolas guineenses é distante da realidade cultural do país (baseada na cultura oral) e das línguas locais: o guineense e diversas línguas étnicas faladas no país.

As consequências da língua portuguesa na escola guineense são bem visíveis: maior índice de as reprovações, abandono escolar e a má qualidade do ensino. Os motivos de tudo isso são: tanto os professores como seus alunos falam as suas línguas cotidianamente em casa e, ao chegar à escola, eles são obrigados a 


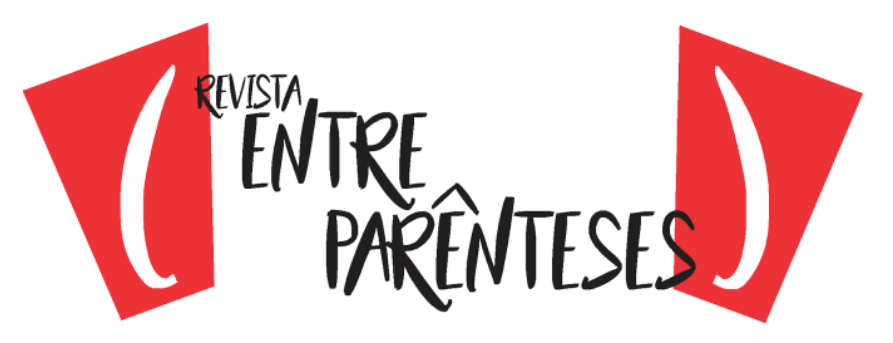

falar português. Uma grande parte dos alunos reprova não porque não são inteligentes ou são incapazes, mas porque não conseguem expressar oralmente e por escrito nessa língua. $O$ que resulta nas suas reprovações e consequentemente provoca abandono escolar.

Imagine como pode ser delicioso e motivador aprender com (i) um livro de matemática que utiliza conhecimento tradicionais dos balanta bassa para explicar o funcionamento de cálculos e resolução de problemas matemáticos; (ii) um livro de história que utiliza provérbios para contar o passado dos balanta brassa ou que fale dos heróis do povo da Guiné-Bissau (iii) um livro de biologia que descreva animais da região onde o aluno se encontra; (iv) um livro de geografia que descreve aspectos do relevo, do clima e da temperatura da região onde o aluno está inserido. Antes de conhecer a História e a Geografia de Portugal e do mundo, o aluno deveria conhecer a História e a Geografia do povo balanta brassa, da Guiné-Bissau e da África antes mesmo de estudar toda a Europa. Ki-Zerbo (2006, p.72) chama atenção da necessidade "regressar à alfabetização e à escolarização em línguas maternas africanas." Ele tem razão. Precisamos regressar, pois antes da colonização já educávamos nosso povo em línguas africanas.

Como é que uma criança que nasceu e cresceu falando balanta pode dominar perfeitamente a norma-padrão do português se é falada apenas com o professor? É que mesmo entre colegas da turma, os alunos falam em voz baixa em guineense ou balanta. A pesquisa recebeu muitas reclamações dos alunos balantas do Sul a respeito das suas dificuldades em aprender o português. Muitos alegam que reprovam porque têm dificuldades de entender a língua o que o professor fala e escrever também é difícil. Escrever não é transcrever. Existem conhecimentos profundos para saber escrever, porque existe uma única chance de escrever uma palavra em português. As opções *kaza, "qasa, "qaza, "caza, *kasa, "caza, khasa, cazha, etc. não servem para escrever a palavra "casa". Tanto a escrita quanto a leitura contribuem para alto índice de reprovações, fato que desmotiva os alunos contribuindo para o abandono escolar. 


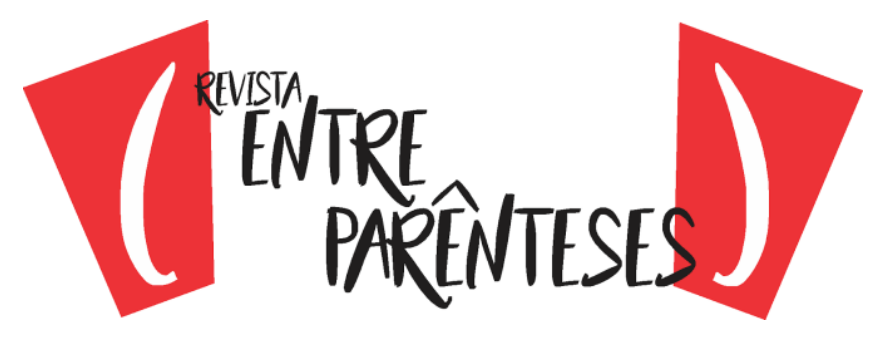

Partimos do princípio de que o aluno não é uma tábua rasa. Ele tem uma bagagem cultural muito importante que deve ser explorada positivamente. Ele tem uma quantidade considerável de conhecimentos adquiridos nos ritos de iniciação, na sua comunidade, na sua casa, etc. (TIMBANE, 2015). Nesse sentido, de acordo com o nosso ponto de vista, deve-se respeitar e valorizar as culturas locais no ensino guineense, especialmente, as línguas locais; deve-se adotar uma metodologia de ensino para a língua portuguesa, ou seja, uma metodologia que a coloca no seu lugar de língua segunda ou língua terceira de muitos alunos guineenses. Também, o Estado da Guiné-Bissau deve investir seriamente nos estudos das línguas locais oficializando-as nas zonas onde elas ocorrem; investir na formação local dos linguistas e outros profissionais da educação voltados para as questões linguísticas; investir seriamente na materialização prática no ensino bilíngue: as línguas étnicas, guineense e a língua portuguesa. Só assim o país pode trilhar rumo a uma educação inclusiva e de qualidade que se espera. Caso contrário, estaremos caminhando longe de uma educação endógena (KI-ZERBO, 2006).

Seria importante tratar a etnografia como um profundo e significativo processo de reflexão epistemológica e da produção de conhecimento, especialmente, da antropologia enfatizando as múltiplas possibilidades da etnografia como método científico aberto a vários domínios da vida social. Seria importante fazer uma análise crítica baseada no olhar da antropologia da educação, a respeito das consequências da política oficial da educação, sobretudo, a política linguística vigente no processo de ensino-aprendizagem na Guiné-Bissau, focando especificamente a etnia balanta brassa no Sul do país

Seria importante discutir através do referencial teórico da antropologia da educação a respeito da necessidade de um diálogo entre educação escolar e a educação da tradição oral praticada pelos diferentes segmentos étnicos da GuinéBissau, especialmente os balanta brassa. Seria importante enfatizar a importância da aplicação das línguas maternas dos alunos na escola, visando não só dialogar com a realidade do aluno, mas, sobretudo, fazer com que o aluno compreenda o mundo a 


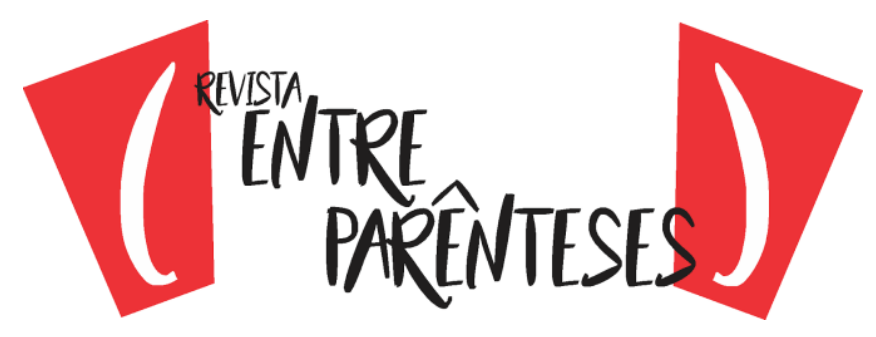

partir da leitura da sua própria realidade, o que na nossa leitura contribuirá no aumento de progressão escolar dos alunos, na diminuição de evasão escolar na promoção da inclusão escolar e na melhoria de qualidade a educação escolar do país. Sendo assim, seria importante analisar e ter a compreensão da tensão entre a escrita e a oralidade na sociedade da cultura oral como a Guiné-Bissau.

A Guiné-Bissau é assinante da carta dos Direitos Linguísticos da Unesco (1996). Sendo assim, a política linguística deveria respeitar o artigo $9^{\circ}$ que defende que "Todas as comunidades linguísticas têm direito a codificar, estandardizar, preservar, desenvolver e promover o seu sistema linguístico, sem interferências induzidas ou forçadas."

\section{Referências}

ALMEIDA, H. M. F. Educação e transformação social: formas alternativas de educação em país descolonizado. 239 p. Rio de Janeiro. Dissertação de Mestrado. Fundação Getúlio Vargas, 1981.

ANTUNES, I. Língua, texto e ensino: outra escola possível. São Paulo: Parábola, 2009.

BÂ, A. H, A Tradição Viva In. KI-ZERBO, J. (Org.). História geral da África I: Metodologia e pré-história da África. 2.ed. Brasília: UNESCO, 2010.

BALSALOBRE, S. R. G. Brasil, Moçambique e Angola: desvendando relações sociolinguísticas pelo prisma das formas de tratamento. 346f. Araraquara-SP. Tese de doutorado. Universidade Estadual Paulista, 2015.

BOURDIEU, P. A economia das trocas linguísticas: o que falar quer dizer. São Paulo: Ed. USP, 1998.

BOURDIEU, P. Economia das trocas simbólicas. São Paulo: Perspectiva, 1987.

BOURDIEU, P.; PASSERON, J. C. A reprodução: Elementos para uma teoria do sistema de ensino. Rio de Janeiro: Francisco Alves, 1970. 


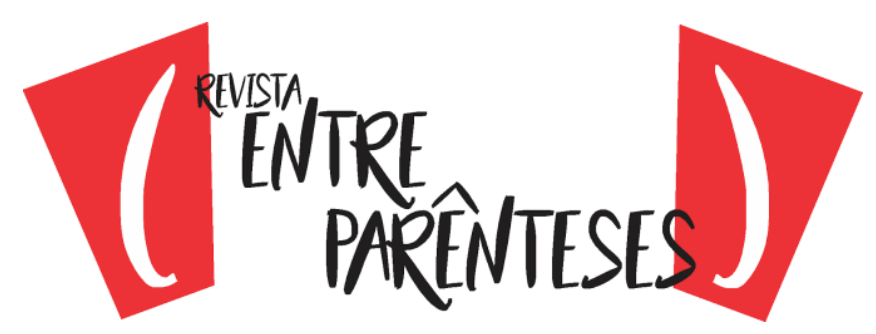

CÁ, V. J. B. Língua e ensino em contexto de diversidade linguística e cultural: o caso de Guiné-Bissau. 175f. Belo Horizonte, MG. Dissertação de Mestrado. Universidade Federal de Minas Gerais, 2015.

CABRAL, A. Análise de alguns tipos de resistências. Bolama: Imprensa Nacional, 1990.

CANDÉ, F. A língua portuguesa na formação de professores do ensino básico da região de Bafatá, na Guiné-Bissau. Dissertação Ensino de Português Como Língua Segunda/ Língua Estrangeira. Faculdade de Ciências Sociais e Humanas. Universidade Nova de Lisboa, 2008.

COUTO, H. H. do. O crioulo português da Guiné-Bissau. Hamburgo: Helmut Buske Verlag, 1994.

COUTO, H. H. do; EMBALÓ, F. Literatura, língua e cultura na Guiné-Bissau: um país da CPLP. Papia. № 20. Brasília, 2010.

CRUZ, A. R. V. Abordagem Comunicativa: enfoque na competência oral na língua segunda, Caso da Guiné-Bissau. 86f. Faculdade de Letras. Universidade do Porto. Porto. 2013.

FREIRE, P. Cartas à Guiné-Bissau: retrato de uma experiência em processo. São Paulo: Paz e terra, 1978.

GUINÉ-BISSAU. Constituição da República da Guiné-Bissau, Bissau, 1973.

GUINÉ-BISSAU. Assembleia Nacional Popular da República. Bissau, 1996.

GUSMÃO, N. M. M. Antropologia, diversidade e educação: um campo e um muitos Caminhos. Ponto-e-vírgula. v.10. p.32-45, 2011.

GUSMÃO. N. M. M. Antropologia e educação: um campo e muitos caminhos. Linhas Críticas, Brasília, DF, v.21, n.44, p. 19-37, jan./abr. 2015.

HAGEN, E. Dialeto, língua, nação. IN: BAGNO, M. (Org.). Normas linguística. São Paulo: Layola, 2001.

INSTITUTO NACIONAL DE ESTATÍSTICA E CENSO. Recenseamento geral da população e habitação v. IV. Bissau: INEC, 1991.

KI-ZERBO, J. Para quando África? Entrevista com René Holenatein. Trad. Carlos Aboim de Brito. Rio de Janeiro: Pallas, 2006 


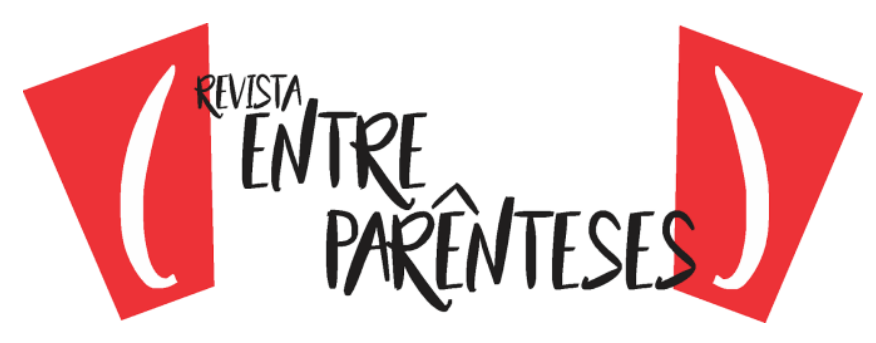

MARCONI, M. de A.; LAKATOS, E. M. Fundamentos de metodologia científica. 5.ed. São Paulo: Atlas, 2003.

MARCUSCHI, L. A. Da fala para a escrita: atividades de retextualização. 10.ed. São Paulo: Cortez, 2010.

NAMONE, D. \& TIMBANE, A. A. Consequências do ensino da língua portuguesa no ensino fundamental na Guiné-Bissau 43 anos após a independência. Mandinga: Revista de Estudos Linguísticos, Redenção-CE, v. 01, n. 01, p. 39-57, jan./jun. 2017.

NAMONE, D. A luta pela independência na Guiné-Bissau e os caminhos do projeto educativo do PAIGC: etnicidade como problema na construção de uma identidade nacional. Araraquara, SP. Dissertação de Mestrado. Universidade Estadual Paulista, 2014. 120 p.

PORTUGAL. Estatuto dos Indígenas Portugueses das Províncias da Guiné, Angola e Moçambique. Aprovado por Decreto-Lei de 20 de Maio de 1954.

ROCHA, G.; TOSTA, S. P. Antropologia e educação. Belo Horizonte: Autêntica, 2009.

SCANTAMBURLO, L. 0 léxico do crioulo guineense e as suas relações com o português: o ensino bilingue português-crioulo guineense. 358f. Tese de doutorado. Universidade Nova de Lisboa, 2013.

TIMBANE, A.A. A variação e a mudança lexical da Língua Portuguesa em Moçambique. 318f. (Tese). Doutorado em Linguística e Língua Portuguesa. Faculdade de Ciências e Letras. Universidade Estadual Paulista, Araraquara, 2013.

TIMBANE, A. A. A complexidade do ensino em contexto multilíngue em Moçambique: políticas, problemas e soluções. Calidoscópio. v.13, v.1, p.92-103, jan./abr. 2015.

TIMBANE, A. A. \& REZENDE, M. C. M. A língua como instrumento opressor e libertador no contexto lusófono: o caso do brasil e de Moçambique. Travessias. v.10, n.3, 28 ed. p.388-408. 2016.

TIMBANE, A. A. NHAVENGE, F. P. A diversidade cultural em África: o caso do casamento tradicional no grupo étnico tsonga do sul de Moçambique. Boletim do Observatório da Diversidade Cultural. v.74, n.4, p.37-50. jul-ago. 2018.

TOSTA, S. P. Antropologia e educação: Interfaces em construção e as culturas na escola. Inter-legere. n.9, p.234-252. 2013. 


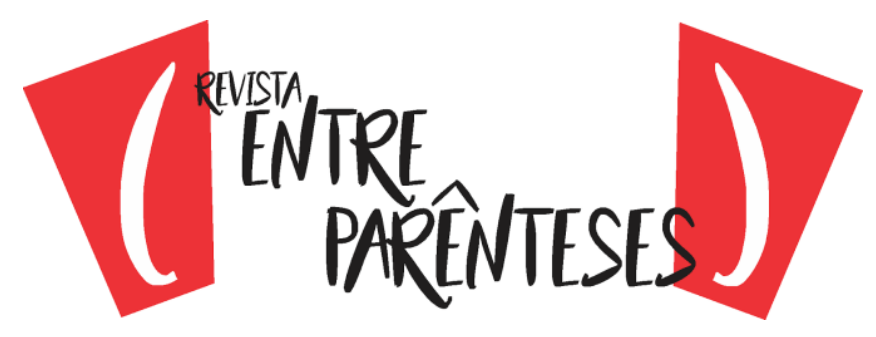

UNESCO. Declaração Universal dos Direitos Linguísticos. Barcelona, junho 1996.

VANSINA, J. A tradição oral e sua metodologia. KI-ZERBO, J. (Org.). História geral da África I: Metodologia e pré-história da África. Brasília: UNESCO, 2010.

ZAMPARONI, V. D. As escravas perpétuas e o ensino prático: raça, gênero e educação no Moçambique colonial, 1910-1930. Estudos afro-asiáticos. Ano 24, no 3. 2002. p. 459-482.

Recebido em 30/09/2018 Aceito em 03/10/2018 